Kelman, I; Lewis, J; Gaillard, JC; Mercer, J; (2015) Island contributions to disaster research. Global Environment , 8 (1) pp. 16-37. 10.3197/ge.2015.080102. Downloaded from UCL Discovery: http://discovery.ucl.ac.uk/1459508

\title{
ARTICLE
}

\section{Island contributions to disaster research}

Ilan Kelman, James Lewis, JC Gaillard, Jessica Mercer

\section{Disaster research and islands: vulnerability and resilience}

Island case studies have contributed significantly to disaster research theory and application, including more recent work on climate change adaptation (CCA). Island-related work in development and disasters has been particularly adept at building on the past in order to create a better development future through disaster risk reduction (DRR; see Kelman et al., 2011; Lewis, 1999; Mercer et al., 2007). This paper details key elements from previous literature of island-based development and disaster research, linking it with a critiquing analysis of ongoing work emerging from climate change. The term 'islands' is used throughout as shorthand for 'islanders, islands and island communities'.

One prominent area is interpreting and understanding the keywords of 'vulnerability' and 'resilience'. Definition, understanding and application of these terms is needed for furthering DRR (including CCA) research, policy and practice. For example, the concepts of vulnerability and resilience (in addition to capacity) have 'played a pivotal role in the progressive emergence of the vulnerability paradigm within the scientific realm' (Gaillard, 2010: 6). This has led to the progressive integration of some of the central ideas from the vulnerability paradigm into some international policy documents such as the Hyogo Framework for Action 2005-2015: Building the Resilience of Nations and Communities to Disasters (UNISDR, 2005). In addition, some governments and non-governmental organisations (NGOs) have capitalised upon these definitions and used them to produce and implement sound policy and practice for DRR, including CCA, and development more generally (Gaillard, 2010). Many authors, as represented in the citations to recent works throughout this paper, are now seeking to meld island studies and disaster research, demonstrating the importance and contributions of islands to disaster literature through examining 'island vulnerability' and 'island resilience' while interrogating the vocabulary to ensure that the definitions are appropriate and applicable.

It was not always that way. Only one earlier research group explicitly recognised the advantages of studying islands: the Bradford Disaster Research Unit (BDRU; http://www.ilankelman.org/bdru.html, with Gane, 1975 and O'Keefe and Conway, 1977 as examples). This unit was founded at the Project Planning Centre, University of Bradford, UK, in the 1970's by the head of the Project Planning Centre, Michael Gane and James Lewis, supported by the Leverhulme Trust. The unit specifically did not adopt a particular discipline or set of disciplines, focusing instead on understanding how to prevent disasters before they happened. With work in the Pacific and the Caribbean complementing studies on UK disasters and general reviews, this work paved the way for exploring disasters and DRR for island vulnerability and island resilience.

Numerous island and disaster studies were nonetheless completed before, during and after BDRU, mostly from mono-disciplinary perspectives such as anthropology (e.g., Spillius, 1957), seismology (e.g., Patterson, 1977), geography (e.g., Baines and McLean, 1976) and meteorology (e.g., Kerr, 1976). The anthropology and human geography research explored 
people's responses to, and capacities for dealing with, everyday aspects of life which are, at times, applied to deal with environmental hazards, including what would today be termed vulnerabilities and resiliences. The physical science references report only physical science data followed by analysis and interpretation of that data, often not addressing any human aspects, as is typical and appropriate for focused, disciplinary work. All this research only occasionally engaged explicitly with island concepts: Campbell (1984), who examined Fijian communities dealing with tropical cyclones using both their own knowledge and external assistance, exemplifies the few non-BDRU authors who did so.

When read today, the disciplinary references on communities reveal intrinsic and innate resilience within island-based communities where hazards were part of day-to-day life. 'Disasters', if locally labelled as such, were frequently unknown and unaided by outsiders. Many of the insights and case studies from this mono-disciplinary literature were published and accepted long before 'resilience' and 'vulnerability' became popular terms; in fact, so popular to the extent that they are now accused of overuse and misuse in much contemporary literature, especially climate change studies (Baldacchino, 2004; Gaillard, 2007, 2010; Lewis and Kelman, 2010; Mercer, 2010).

Climate change is nonetheless an important, contemporary hazard driver common to all islands, and the entire globe, which highlights understandings and conceptualisations of vulnerability and resilience. Despite the importance of climate change, it is one hazard driver amongst many within DRR (Shaw et al., 2010ab). One lesson from the previous island and disasters work is that separating DRR and CCA - even considering them to be separate sectors - is disadvantageous and counterproductive, especially considering that CCA sits well as a subset within ongoing DRR work (Kelman and Gaillard, 2010). Yet much of DRR's research, policy and practice, especially from islands, has not been factored into many contemporary studies focusing on current CCA.

Global climate change caused by human gas emissions and land use choices has been a concern since at least the nineteenth century (e.g., Arrhenius, 1896). The contemporary assessment of the problem is often attributed to beginning with Revelle and Suess (1957) or, sometimes, through MIT (1970, 1971); see also Weart (2008) who gives a detailed history of climate change science. The topic is now embodied by the Intergovernmental Panel on Climate Change (IPCC) which issued its first report in 1990 (IPCC, 1990). The IPCC's mandate is to review, synthesise and assess scientific literature on climate change and potential associated consequences, with its reports representing a political consensus of that process. The most recent work is the Fifth Assessment Report (IPCC, 2013-14), while a report particularly pertinent to DRR is IPCC (2012) - the IPCC Special Report on Managing the Risks of Extreme Events and Disasters to Advance Climate Change Adaptation (SREX). Much of this work emphasises vulnerability and resilience yet does not fully account for previous literature on the topic.

The IPCC (2013-14, in the IPCC WGII AR5 Glossary) definitions include:

-Vulnerability: The propensity or predisposition to be adversely affected. Vulnerability encompasses a variety of concepts including sensitivity or susceptibility to harm and lack of capacity to cope and adapt. See also Contextual vulnerability and Outcome vulnerability'.

-Contextual vulnerability (starting-point vulnerability): A present inability to cope with external pressures or changes, such as changing climate conditions. Contextual vulnerability is a characteristic of social and ecological systems generated by multiple factors and processes'.

- Outcome vulnerability (end-point vulnerability): Vulnerability as the end point of a sequence of analyses beginning with projections of future emission trends, moving on to the development of climate scenarios, and concluding with biophysical impact studies and the identification of adaptive options. Any residual consequences that remain after adaptation has taken place define the levels of vulnerability'. 
These definitions zoom in almost exclusively on climate change while requiring definitions of other jargon such as 'sensitivity or susceptibility to harm' and 'adaptation'. In naming only 'changing climate conditions' and 'climate scenarios' as the possible concerns interacting with vulnerability, the potential exists for difficulties to emerge in applying these definitions beyond climate change. In particular, DRR and development encompass climate change, yet vulnerability emerges from much more than 'projections of future emission trends, moving on to the development of climate scenarios, and concluding with biophysical impact studies and the identification of adaptive options'.

The definitions from IPCC (2013-14) further state directly that vulnerability has a starting point and an ending point, rather than accepting the development and disasters view epitomised in the island examples given earlier - that vulnerability is much more than a fixed sequence that can be delineated in space and time; rather, they are a process (e.g., Hewitt, 1983, 1997; Lewis, 1999, 2009; Wisner et al., 2004, 2012). The IPCC's (2013-14) definitions are commendable in referring to 'multiple factors and processes' yet the glossary does not refer to the literature (e.g., Hewitt, 1983, 1997; Lewis, 1999, 2009; Wisner et al., 2004, 2012) which first theorised and evidenced vulnerability and resilience as long-term processes.

For resilience, IPCC's (2013-14, in the IPCC WGII AR5 Glossary) definition is: 'The capacity of a social-ecological system to cope with a hazardous event or disturbance, responding or reorganising in ways that maintain its essential function, identity, and structure, while also maintaining the capacity for adaptation, learning, and transformation'. This definition is also filled with jargon and does not account for the history and wide scope of the term (see Alexander, 2013).

The ethos behind the IPCC's (2013-14) definition emerges from textbook definitions in ecology (e.g., Townsend et al., 2003), particularly the use of the term 'disturbance' and the assumption that 'essential function, identity, and structure' can and should be maintained rather than changing fundamentally. Yet observations and analyses of ecosystems from the perspective of ecosystem science are from a deliberately removed external viewpoint. The assumptions used to be that ecosystems are an entity observed externally and that they can be analysed as such. In disaster-related development work, ecological processes are not assumed to be benign or neutral, but can help or hinder development endeavours - or be used to help or hinder DRR. Hence, the field of ecosystem-based DRR (Renaud et al., 2013) and, not quite adopting the IPCC's (2013-14) approach, even climate change now has ecosystem-based CCA (Perez et al., 2013). Furthermore, the IPCC's (2013-14) definition implicitly assumes that some form of 'capacity' inevitably survives the 'hazardous event or disturbance', rather than the often-observed reality that capacity can be annihilated or lessened by the hazard, by preceding vulnerability, or by both hazard and vulnerability combining to form a disaster (Lewis, 2009, 2013).

In fact, it is feasible that disturbances could be coped with despite capacity being reduced and all the while maintaining vulnerability. This makes the system both resilient and vulnerable - but to different processes and phenomena. Alternatively, the goal could be to reduce vulnerability, which at times could and should entail effecting fundamental change, with or without a hazard, disturbance or disaster. It is reasonable to suggest that this criticism is accounted for by the phrase in IPCC's (2013-14) definition 'maintaining the capacity for adaptation, learning, and transformation' - but then the two parts of the definition contradict each other, plus the added challenge emerges of defining 'adaptation, learning, and transformation'.

By assuming starting and ending points for vulnerability while relying on ecosystem science for resilience, the IPCC (2013-14) sets the stage for calculating absolute metrics for vulnerability and resilience. Proportional and qualitative approaches are important too, however (Lewis, 1979a, 1999). Lewis $(1999,2009)$ uses island case studies to describe why 
proportional impact, indicative of proportional vulnerability and proportional resilience, each provide important information for development activities. For instance, islands have small populations relative to cities. Even if all of an island country's population is affected by a cyclone, that situation is unlikely to match the numbers of people who would be affected in a megacity with only one percent of the population affected. Yet one hundred percent of a population affected has aspects which can be much worse than one percent of a population affected, such as neighbours, compatriots and one's national government being unable to assist. Absolute and proportional metrics provide different characteristics of vulnerability and resilience, so a key island lesson is that both are needed, even though climate change studies tend to focus on absolute characteristics.

Fundamentally, vulnerability and resilience are societal processes leading to impacts upon ourselves, others and the environment (see also, amongst many, Manyena, 2006; Weichselgartner, 2001; Wisner, 1993). The history and root causes from which vulnerability and resilience emerge (e.g., Lewis, 1979a; Timmerman, 1981), as exemplified in island case studies shown by the work of BDRU and others referenced in this paper, have always been of concern in disaster-related development work and are not explicitly reflected in the IPCC's (2013-14) definitions.

IPCC's (1990, 2012, 2013-14) work is not original in itself, nor is it meant to be. Nonetheless, the limitations in the conceptual aspects of vulnerability and resilience raise questions regarding the IPCC's robustness with respect to past literature, including work involving DRR and islands, and queries why it has not been fully reviewing, synthesising, and assessing the literature. The 'vulnerability process' and 'resilience process' refer to the values, ideas, behaviours and actions that have led to characteristics such as ability or inability to deal with disaster along with characteristics that could perpetuate or absolve the concerns (e.g., Crush, 1995; Hewitt, 1983, 2007; Lewis, 1999; Wisner et al., 2004, 2012). Processes of vulnerability and resilience are frequently perpetrated in the actions and activities of others who are sometimes remote from and beyond the influence or control of those most affected.

When people do affect their own vulnerability, that may be due to a lack of awareness or from inappropriate decision making (especially for more affluent people who have choices and resources), but it more often stems from the root causes of vulnerability as embedded in development topics. Examples are limited livelihood options; restricted land use; external exploitation of people, places and resources; and perpetuating poverty, lack of control and oppression (for islands see also Pelling and Uitto, 2001). These actions can lead to environmental changes such as deforestation, or can expose people to regular environmental phenomena and processes such as floods and earthquakes, which then become hazards. Without options and access to growing adequate food crops, to maintain adequate livestock, or to access adequate employment, resources or services, people and communities are made to become marginalised, disadvantaged and exploited. That is, they are made to become increasingly vulnerable (Hewitt, 1983; Lewis and Kelman, 2012; Wisner et al., 2012).

Resilience, like vulnerability, is a long-term process. Where disasters do not happen, then the resilience process should be acknowledged as 'disasters averted'. When people affect their own resilience, as with vulnerability, it might be advertent, but more often it is because people wish to take control of their own situations and to avoid disasters. They do the best that they can with the resources and options available - usually far too meagre, as on many island communities. Often, the perpetration of vulnerability inhibits people's desire regarding their resilience.

The above critiques of the contemporary climate change work and the alternative approaches suggested have their basis in studies on islands, notably through BDRU as a baseline. A similar, contemporary contribution was the UNESCO/UNFPA Population and 
Environment Project in the Eastern Islands of Fiji, Man and the Biosphere Programme, 1974-76 (http://www.islandvulnerability.org/mabfiji.html). This is not claiming that island case studies were the only contribution towards the literature, nor is it claiming that they are the only ones neglected by some contemporary work. See, for instance, the non-island work from BDRU plus contemporaneous publications on the 1968-74 sub-Saharan Africa drought (e.g., Copans, 1975; Cuny, 1983; Glantz, 1976; O'Keefe et al., 1976). The analysis does show the leading role played by island-related work and how island case studies form a significant portion of that literature. The development of climate change work, as exemplified by theories of vulnerability and resilience, is notably divorced from these case studies and could learn more from previous work. The next section takes a practical example - that of island migration - to explore these issues beyond the definitions and their critiques.

\section{Island migration}

Within climate change, one impact epitomising the lessons from (and for) islands is sea-level rise. While islands have contributed significantly to bringing sea-level rise onto the international agenda in order to emphasise the need to tackle contemporary climate change impacts, islands also demonstrate how much has been forgotten in contemporary climate change discussions, similarly to the discussion on vulnerability and resilience.

Plenty is published regarding discourses of 'drowning islands' and 'climate change refugees' from islands and low-lying coastal locations. Little is based on empirical evidence, as shown by Webb and Kench (2010) who found little field data showing that islands are vulnerable or disappearing due to observed sea-level rises. Meanwhile, Hartmann (2010) and Farbotko $(2005,2010)$ deconstruct the discourses dominating climate change related displacement. Hartmann (2010) analyses the literature theoretically, tracing its obsession with 'climate refugees' to ideological rather than scientific foundations while suggesting this view to be part of an agenda to militarise development aid and climate change responses. Farbotko (2005, 2010) uses empirical work on discourses about Tuvalu, showing how portraying the islanders as both victims (of climate change) and saviours (through traditional practices) ends up iconising the Tuvaluans as heroes while marginalising their views, interests, abilities and resilience regarding climate change. These publications and their analyses do not conform to popular discourse and are frequently bypassed by other researchers.

For example, no papers in Warner and Afifi (2011) refer to these other references or apply the knowledge gleaned from the island literature, as referenced throughout this paper. Two papers in Black et al. (2011) reference Hartmann (2010); otherwise, the critical literature is mainly absent. The IPCC's new 'Human Security' chapter (IPCC 2013-14, chapter 12) lists Hartmann (2010) at the end, but does not cite it in the main text - while the entire chapter is weak on citing the island-related security literature, as referenced throughout this paper.

The critical views of, and lack of empirical evidence for, masses of islands disappearing due to climate change are gaining increased traction with more recent papers. Bettini (2013) and Nicholson (2014) argue theoretically, challenging the need for apocalyptic and dystopian narratives and providing alternatives to the intense focus on trying (and often failing) to establish a direct causal link between climate change and migration. They are concerned about the depoliticisation of climate change and migration work which does not always fully acknowledge or accept issues of power, resource distribution and marginalisation (see also Felli and Castree, 2012). Meanwhile, Ballu et al. (2012) and Rankey (2011) demonstrate further the lack of empirical evidence for islands sinking or disappearing due to sea-level rise. Another concern is that island evacuation due to sea-level rise or other climate change impacts is presented as new and original without precedent. Yet volcanic eruptions on islands have been involved in many forced migrations from islands, including many instances when return was not expected to be an option, just like sea-level rise. These case studies date back a long way, with three examples reviewed briefly here. 
Lewis (1979b) describes the eruption on the Tongan island of Niua Fo'ou in 1946 (see also Rogers, 1981), as recounted to him by Moeake Tokai, who was 20 years old at the time but who kept a detailed diary of events. On 9 September, the volcano erupted soon after an earthquake and the approximately 2,500 islanders evacuated the town as lava and ash encroached. They waited four days until a passing US Navy plane spotted the volcano's smoke, and then the evacuees, and the crew informed Tonga's capital. Four days later, a government ship arrived with the government officer suggesting full evacuation.

The community voted. The people, represented by three chiefs, favoured evacuation, but a group of 700 , represented by a fourth chief, were against. Majority rules, so everyone was evacuated to Tonga's main island, Tongatapu, on 21 December 1946. Preparations began for permanent resettlement on the island of 'Eua. Those in favour of evacuation began moving to 'Eua in September 1948, with their community remaining there today. The 700 who voted against remained on Tongatapu until they convinced the Tongan government to assist their return to Niua Fo'ou in 1959, with their community still residing there. From 195053 several groups of men returned to Niua Fo'ou for short periods to work on copra production and re-taming the animals which had been left behind during the evacuation.

Tristan da Cunha (with this case study summarised from de Boer and Sanders, 2002 and Mackay, 1963) in the South Atlantic belongs to the UK and has long had a population of just a few hundred people collected in a single settlement. In 1961, the volcano forming the island erupted with a lava flow threatening the settlement, and so the residents evacuated, ending up in England. A major disagreement erupted between the evacuated islanders and the UK authorities regarding returning to Tristan da Cunha when the UK government tried to impose a decision of non-return. The islanders disagreed and held a poll in which the majority voted to return. First, a group of 51 left England on 17 March 1963, arriving on Tristan da Cunha on 9 April 1963. The second group, of 198, left on 24 October 1963 and arrived back to their island on 10 November 1963. The rest returned in 1964. Only 16 people, all of them in the younger age group, decided not to return. Tristan da Cunha continues as a community today with just under 300 inhabitants and still lacks either an airport or a large harbour.

The third case study is the island of Heimaey in Iceland's Vestmannaeyjar Archipelago (Chester, 1993; Williams and Moore, 1983). In the middle of the night of 23 January 1973, a new fissure suddenly opened up and started spewing lava near the island's only town. Most of the island's 5,300 residents were evacuated. The eruption ceased approximately four months later, with 300 houses destroyed by fire, the town covered in ash up to six metres thick and the only harbour being nearly closed in by lava encroaching into the sea. Soon after the volcano stopped, return and reconstruction began in the shadow of a new mountain, using the volcano's materials as assets. Geothermal heat was tapped, the tephra used for paving materials, and the lava cooled by and hardened in the sea forms a breakwater that shelters the harbour. Heimaey is now a thriving fishing, farming and tourist village.

Precedents are not just volcanoes but also climate, as discussed by Nunn (2000, 2001), Nunn and Britton (2001) and Nunn et al. (2007) with respect to fourteenth-century environmental and cultural changes around the Pacific. These authors document major and sudden environmental changes termed the 'AD 1300 Event' during which the regional climate cooled, sea level fell exposing coral reefs, the frequency of El Niño events likely increased and a short-term increase in precipitation seems to have occurred. At the same time, major and sudden shifts in living patterns were seen. Accessible coastal settlements were abandoned in favour of locations which, were or, could be fortified. The success of long oceanic voyages and the frequency of inter-island exchange diminished rapidly while the authors point to evidence for reduced food security and increased conflict. The conclusion from the papers is that these Pacific social and cultural changes were both correlated to and caused by the environmental changes. 
These island case studies from volcanoes and climate show how analogies and precedents exist that could inform contemporary discussion of possible island evacuation under climate change. Yet they are rarely permitted to. Again, for example, none of this work is referenced in Black et al. (2011) or Warner and Afifi (2011). There are differences between volcano evacuation and climate change evacuation, as there are differences between the past and the present. Using analogies can nonetheless help, especially to recognise the lessons that do and do not apply.

The media feed into the rhetoric, especially aiming to highlight vulnerability while downplaying resilience. In July 2004, the international media blazed with headlines of the world's first so-called 'climate change refugees' from the island village of Shishmaref, Alaska. Then, in December 2005, the international media again reported the world's first so-called 'climate change refugees', but this time from the Lateu settlement in Vanuatu. The islanders were said to have moved inland due to sea-level rise leading to more frequent flooding. Subsequent research (Ballu et al., 2012) revealed that most of the inundation was due to seismic subsidence. In September 2007, yet again headlines reported the world's first 'climate change refugees' when people from PNG's Carteret Islands themselves started a migration process as rising sea levels encroached on their villages.

In some instances such as the Carteret Islands and Shishmaref, the migration is motivated exclusively by climate change (Bronen and Chapman III, 2014; Yamamoto and Esteban, 2014). That does not excuse some contemporary climate change discussions from neglecting other work and from excluding research which does not conform to pre-conceived notions. Both involve many of the island-related seminal publications referenced in this paper, the point of which is to avoid iconising islands with respect to climate change impacts and responses.

Another example of older work relevant to contemporary discussions is the Small States Conference on Sea Level Rise, which was held 14-18 November 1989 in Malé, the Maldives (http://www.islandvulnerability.org/slr1989.html). The conference brought together islander and non-islander scientists, along with many other islanders including decision makers. The discussion led to the Malé Declaration on Global Warming and Sea Level Rise. That declaration painted a scenario of a global average temperature rise of $1-2^{\circ} \mathrm{C}$ by 2030 , described the difficulties that sea-level rise will pose for small island states and wanted the more affluent countries to share resources with less affluent countries including technology, funds and training assistance to address climate change. Little has changed fundamentally in these calls since the conference - apart from the projections of temperature rise and subsequent impacts becoming more dramatic (IPCC, 2013-14).

From that conference, Lewis $(1989,1990 \mathrm{abc})$ published some of the earliest peer-reviewed scientific papers on low-lying atolls and sea-level rise (see also Nunn, 1988, 1990). The importance is highlighting the islands for an externally created vulnerability, since the islanders have contributed negligibly to climate change, while promoting islander views of the challenges they face and of their own resilience. This work was specifically operational, seeking action, but resulted in cutting-edge and pioneering scientific publications. Yet more modern literature bypasses that work, introducing myths such as Janssen et al. (2006) implying that Liverman (1990) - a piece not covering islands - was the first publication to link 'the term vulnerability to global environmental change' (Janssen et al., 2006: 248).

The weight of this earlier work, namely from island case studies, does not stop climate change discourses from iconising islands. Sometimes the islanders themselves are effective at this. In 2002, Tuvalu's Prime Minister threatened a court case against the US government under George W. Bush and the Australian government under John Howard for causing climate change because those leaders refused to ratify the Kyoto Protocol (Jacobs, 2005). The court case foundered when the Tuvaluan Prime Minister was voted out of office. 
As another example, the Maldives' president from 2008-12, Mohamed Nasheed, highlighted climate change as threatening his country. On 10 November 2008, before he had even been sworn in, he committed to setting up a fund which would be used to purchase new land to which the Maldivians would move. On 15 March 2009, he declared that the Maldives would become carbon neutral by 2020, although it was unclear how fossil fuel use from shipping and aviation would be factored into the calculations. Later that year, on 17 October 2009, he held an underwater cabinet meeting in the sea to highlight the 'drowning islands' and 'vulnerable islands' narrative. Without denying the threat to the Maldives from climate change, many other devastating development challenges need to be overcome - from energy supply (van Alphen et al., 2008) to gender equity (Fulu, 2007). During his tenure as president, Nasheed did not make an international case for solving these development challenges. Climate change has perhaps become a convenient distraction from those development challenges on the Maldives which, as Kothari (2014) points out, have existed for decades.

In Kiribati, a similar gap between the rhetoric of climate change and the reality of life in the archipelago has been observed (Gaillard, 2012). The dominant discourse on the potential long-term impact of climate change, including migration, as promoted by the country's president Anote Tong, obscures the day-to-day livelihood-related concerns of local communities. Most of the multimillion dollar climate change-related projects yield limited outcomes, whilst at the community level funding is often siphoned off to sustain short-term needs, such as paying for school fees and food.

Many researchers have latched onto the popular discourse entirely uncritically without fully investigating it, especially in order to highlight perceived vulnerabilities. Some literature (e.g., Adger and Barnett, 2005; Pilkey and Young, 2009) describes how New Zealand started a new scheme to admit people from Kiribati and Tuvalu as part of the first wave of climate refugees. The only scheme available is New Zealand's special Pacific Access Category which is an agreement with Kiribati, Tuvalu and Tonga to permit several dozen citizens from each country to emigrate to New Zealand each year. Neither mentions of climate change or environmental change were found in any of the official documentation, with the scheme instead describing that 'work opportunities, education and family are some of the reasons people choose to leave the Pacific Islands and start a new life in New Zealand, and many have found New Zealand a great place to live, work and raise families' (http://www.immigration.govt.nz/migrant/stream/live/pacificaccess).

Similarly, little of the climate change literature iconising islands engages extensively with the rich and long literature of disaster research or island studies, particularly the vast literature on island representation and representing islands (e.g., Baldacchino, 2007; Geografiska Annaler, Series B: Human Geography, 2005; and Human Ecology, 2007). Overall, climate change research has limited engagement with the very material that it purports to represent, such as island vulnerability and island resilience. This is an island lesson that should be learned beyond islands. Whether dealing with change affecting arid lands (e.g., Mol and Sternberg, 2012) or megacities (e.g., Pelling and Wisner, 2009), it is important to recognise the use and abuse of iconisation - of which islands are usually a prominent example (e.g., Beer, 1997; Jackson and Della Dora, 2009). This also means learning from science that has long been published, of which disaster research, often with island case studies, is a prominent example.

\section{Conclusions: many strong voices}

The extensive island contributions to disaster research, particularly regarding vulnerability and resilience, provide an understanding of past work - the theoretical material and use in a practical case study, such as island migration - and an acceptance of wider topics and literature. This means not focusing on a single hazard driver such as climate change or even 
a single hazard such as storms or earthquakes. Instead, it is about recognising the need not only to seek an all-hazards approach, but also to go beyond a hazard focus and to embrace an all-vulnerabilities and all-resiliences approach.

One programme doing so, drawing on the theoretical and practical lessons described above, is Many Strong Voices (MSV; http://www.manystrongvoices.org) co-directed by one author of this paper (Kelman) along with a Norwegian organisation named GRID-Arendal. MSV seeks to tackle some of these myths described above and to inject island lessons and research into contemporary climate change discussions (see CICERO and UNEP/GRID-Arendal, 2008; Kelman, 2010, 2011; Kelman and West, 2009; Kelman and Gaillard, 2009, 2010). The programme started in 2005 at the request of peoples from the Arctic (many of whom live on islands such as Greenland and Baffin Island) and Small Island Developing States (SIDS, such as the British Virgin Islands and the Seychelles) to support local voices and local abilities for addressing climate change impacts.

The Arctic and SIDS peoples have many differences due to their regions' climates and histories, but they also display numerous similarities. Examples are natural resource dependency and, in many cases, being relatively isolated coastal communities. Their voices, knowledge and wisdom tend to be sidelined, in terms of not only describing their observations of their changing climate, but also providing possible solutions from their own experiences and abilities as well as possible solutions for which they are requesting outside assistance.

MSV activities are about information sharing, story exchange and capacity building, especially for influencing international fora, and mutual support for decision making and networking to learn from each other. Scientific research is being conducted and published (http://www.islandvulnerability.org/docs/islandsclimatechange.pdf) providing a baseline for understanding the needs of MSV participants. In this research and application, climate change is placed as part of wider and deeper development tasks in which island and nonisland Arctic lessons inform wider climate change work.

By consolidating the material and approaches described throughout this paper, MSV shows the importance of tackling climate change, especially for islands, but it must always be climate change situated within wider disaster and development tasks. Many of the innovative ideas and practical implementation approaches emerge from work on islands, suggesting that more effort is needed to help transfer island experiences to other locations - and vice versa. That includes better embracing previous and wider work - research, policy and practice - in order to have an improved approach to DRR, incorporating the hazard driver of climate change without letting it dominate, based on learning from (without becoming mired in) the past. This lesson summarises island contributions to disaster research.

\section{References}

Adger, N. and J. Barnett. 2005. 'Compensation for climate change must meet needs'. Nature 436: 328.

Alexander, D.E. 2013. 'Resilience and disaster risk reduction: an etymological journey'. Natural Hazards and Earth Systems Sciences 13: 2707-2716.

Arrhenius, S. 1896. 'On the Influence of Carbonic Acid in the Air upon the Temperature of the Ground'. The London, Edinburgh, and Dublin Philosophical Magazine and Journal of Science (Fifth Series) 41: 237-276.

Baines, G.B.K. and R.F. McLean. 1976. 'Re-Surveys of 1972 Hurricane Rampart of Funafuti Atoll, Ellice Islands'. Search 7: 36-37.

Baldacchino, G. 2004. 'Moving away from the Terms Vulnerability and Resilience in Small Islands'. Wise Coastal Practices for Sustainable Human Development Forum, Thursday, 11 March 2004, at 11:13 a.m., http://www.csiwisepractices.org/?read=490 
Baldacchino, G. (ed). 2007. A World of Islands: An Island Studies Reader. Charlottetown, Canada and Luqa, Malta: Institute of Island Studies and Agenda Academic.

Ballu, V., M.N. Bouin, P. Siméoni, W.C. Crawford, S. Calmant, J.M. Boré, T. Kanas and B. Pelletier. 2012. 'Comparing the role of absolute sea-level rise and vertical tectonic motions in coastal flooding, Torres Islands (Vanuatu)'. PNAS 108: 13019-13022.

Beer, G. 1997. 'The Making of a Cliché: "No Man is an Island"'. European Journal of English Studies 1: 33-47.

Bettini, G. 2013. 'Climate Barbarians at the Gate? A critique of apocalyptic narratives on 'climate refugees'. Geoforum 45: 63-72.

Black, R., N. Adger, N.W. Arnell, S. Dercon, A. Geddes and D.S.G. Thomas. 2011. 'The effect of environment change on migration'. Global Environmental Change 21: S3-S11.

Bronen, R. and F. Stuart Chapin III. 2014. 'Adaptive governance and institutional strategies for climate-induced community relocations in Alaska'. Proceedings of the National Academy of Sciences, forthcoming.

Campbell, J.R. 1984. Dealing with Disaster: Hurricane Response in Fiji. Honolulu, Hawai'i: East-West Center.

Chester, D.K. 1993. Volcanoes and Society. London: Edward Arnold.

CICERO and UNEP/GRID-Arendal. 2008. Many Strong Voices: Outline for an assessment project design. CICERO Report 2008:05. Oslo: CICERO (Center for International Climate and Environmental Research, Oslo).

Copans, J. (ed). 1975. Sécheresses et famines du Sahel. Paris: F. Maspero.

Crush, J. (ed). 1995. Power of Development. London: Routledge.

Cuny, F. 1983. Disasters and development. Oxford: Oxford University Press.

de Boer, J.Z. and D.T. Sanders. 2002. Volcanoes in Human History. Princeton, New Jersey: Princeton University Press.

Farbotko, C. 2005. 'Tuvalu and Climate Change: Constructions of Environmental Displacement in the Sydney Morning Herald'. Geografiska Annaler B 87: 279-294.

Farbotko, C. 2010. "The global warming clock is ticking so see these places while you can": Voyeuristic tourism and model environmental citizens on Tuvalu's disappearing islands'. Singapore Journal of Tropical Geography 31: 224-238.

Felli, R. and N. Castree. 2012. 'Neoliberalising adaptation to environmental change: foresight or foreclosure?' Environment and Planning A 44: 1-4.

Fulu, E. 2007. 'Gender, Vulnerability, and the Experts: Responding to the Maldives Tsunami'. Development and Change 38: 843-864.

Gaillard, J.C. 2007. 'Resilience of Traditional Societies in Facing Natural Hazards'. Disaster Prevention and Management 16: 522-544.

Gaillard, J.C. 2010. 'Vulnerability, Capacity, and Resilience: Perspectives for Climate and Disaster Risk Reduction'. Journal of International Development 22: 218-232.

Gaillard J.C. 2012. The climate gap. Climate and Development 4: 261-264.

Gane, M. 1975. Report of a Mission to Assess the Hurricane Factor for Planning Purposes in Fiji. Bradford Disaster Research Unit Occasional Paper 9. Bradford: University of Bradford.

Geografiska Annaler, Series B: Human Geography. 2005. Special issue on 'Islands Objects of Representation' 87: 247-305.

Glantz, M.H. (ed). 1976. The Politics of Natural Disaster. New York, New York: Praeger.

Hartmann, B. 2010. 'Rethinking climate refugees and climate conflict: rhetoric, reality and the politics of policy discourse'. Journal of International Development 22: 233-246.

Hewitt, K. (ed). 1983. Interpretations of Calamity from the Viewpoint of Human Ecology. London: Allen \& Unwin.

Hewitt, K. 1997. Regions of Risk: A Geographical Introduction to Disasters. Essex: Addison Wesley Longman.

Hewitt, K. 2007. 'Preventable disasters: addressing social vulnerability, institutional risk, and civil ethics'. Geographische Rundschau International Edition 3: 43-52.

Human Ecology. 1997. Special issue on 'Islands as Laboratories' 25: 379-518.

IPCC. 1990. IPCC First Assessment Report. Geneva: IPCC (Intergovernmental Panel on Climate Change). 
IPCC. 2012. Managing the risks of extreme events and disasters to advance climate change adaptation: a special report of working groups I and II of the Intergovernmental Panel on Climate Change. Cambridge: Cambridge University Press.

IPCC. 2013-2014. IPCC Fifth Assessment Report. Geneva: IPCC (Intergovernmental Panel on Climate Change).

Jackson, M. and V. Della Dora. 2009. 'Dreams so big only the Sea can hold them: Manmade Islands as Anxious Spaces, Cultural Icons, and Travelling Visions'. Environment and Planning A 41: 2086-2104.

Jacobs, R.E. 2005. 'Treading Deep Waters: Substantive Law Issues in Tuvalu's Threat to Sue the United States in the International Court of Justice'. Pacific Rim Law and Policy Journal 14: 103-128.

Janssen, M.A., M.L. Schoon, W. Ke and K. Börner. 2006. 'Scholarly networks on resilience, vulnerability and adaptation within the human dimensions of global environmental change'. Global Environmental Change 16: 240-252.

Kelman, I. 2010. 'Hearing local voices from Small Island Developing States for climate change'. Local Environment 15: 605-619.

Kelman, I. 2011. 'Dealing with Climate Change on Small Island Developing States'. Practicing Anthropology 33: 28-32.

Kelman, I. and J.C. Gaillard. 2009. 'Challenges and Opportunities of Disaster-Related Public Anthropology'. Asian Journal of Environment and Disaster Management 1: 119-139.

Kelman, I. and J.C. Gaillard. 2010. 'Embedding Climate Change Adaptation Within Disaster Risk Reduction'. In R. Shaw, J.M. Pulhin and J.J. Pereira (eds), Climate Change Adaptation and Disaster Risk Reduction: Issues and Challenges, pp.23-46. Bingley: Emerald Group Publishing Limited.

Kelman, I., J. Lewis, J.C. Gaillard and J. Mercer. 2011. 'Participatory action research for dealing with disasters on islands'. Island Studies Journal 6: 59-86.

Kelman, I. and J. West. 2009. 'Climate Change and Small Island Developing States: A Critical Review'. Ecological and Environmental Anthropology 5: 1-16.

Kerr, J.S. 1976. Tropical Storms and Hurricanes of the South Pacific: Nov 1939-April 1969. Miscellaneous Publication No. 148. Wellington: New Zealand Meteorological Service.

Kothari, U. 2014. 'Climate Change and Migration: A Political Discourse of Resettlement in the Maldives'. The Geographical Journal 180: 130-140.

Lewis, J. 1979a. 'The Vulnerable State: An alternative view'. In L. Stephens and S.J. Green (eds), Disaster Assistance: Appraisal, Reform and New Approaches, pp.104-129. New York, New York: New York University Press.

Lewis, J. 1979b. 'Volcano in Tonga'. Journal of Administration Overseas XVIII: 116-121.

Lewis, J. 1989. 'Sea-level Rise: Some Implications for Tuvalu'. Ambio 18: 458-459.

Lewis, J. 1990a. 'Small States Conference on Sea Level Rise'. The Environmentalist 10: 141-143.

Lewis, J. 1990b. 'Small States Conference on Sea Level Rise, Malé, Republic of the Maldives, 14-18 November 1989'. Disasters 14: 77-78.

Lewis, J. 1990c. 'The Vulnerability of Small Island States to Sea Level Rise: The Need for Holistic Strategies'. Disasters 14: 241-248.

Lewis, J. 1999. Development in Disaster-prone Places: Studies of Vulnerability. London: Intermediate Technology Publications.

Lewis, J. 2009. 'An Island Characteristic: Derivative Vulnerabilities to Indigenous and Exogenous Hazards'. Shima: The International Journal of Research into Island Cultures 3: 3-15.

Lewis. J. 2013. 'Some realities of resilience: A case study of Wittenberge'. Disaster Prevention and Management 22: 48-62.

Lewis, J. and I. Kelman. 2010. Places, People and Perpetuity: Community Capacities in Ecologies of Catastrophe. ACME: An International E-Journal for Critical Geographies 9: 191220.

Lewis, J. and I. Kelman. 2012. 'The Good, The Bad and The Ugly: Disaster Risk Reduction (DRR) Versus Disaster Risk Creation (DRC)'. PLoS Currents Disasters, 21 June 2012, 
http://currents.plos.org/disasters/article/the-good-the-bad-and-the-ugly-disaster-riskreduction-drr-versus-disaster-risk-creation-drc

Liverman, D.M. 1990. 'Vulnerability to global environmental change'. In R.E. Kasperson, D.G. Dow and J.X. Kasperson (eds), Understanding Global Environmental Change: The Contributions of Risk Analysis and Management, pp.27-44. Worchester, Massachusetts: Clark University.

Mackay, M. 1963. Angry Island: The Story of Tristan da Cunha 1506-1963. New York: Rand McNally \& Company.

Manyena, S.B. 2006. 'The concept of resilience revisited'. Disasters 30: 433-450.

Mercer, J. 2010. 'Disaster Risk Reduction or Climate Change Adaptation: Are We Reinventing the Wheel?' Journal of International Development 22: 247-264.

Mercer, J., D. Dominey-Howes, I. Kelman and K. Lloyd. 2007. 'The Potential for Combining Indigenous and Western Knowledge in Reducing Vulnerability to Environmental Hazards in Small Island Developing States'. Environmental Hazards 7: 245-256.

MIT (Massachusetts Institute of Technology). 1970. Man's Impact on the Global Environment. Report of the Study of Critical Environmental Problems (SCEP). Cambridge, Massachusetts: MIT Press.

MIT (Massachusetts Institute of Technology). 1971. Inadvertent Climate Modification. Report of the Study of Man's Impact on Climate (SMIC). Cambridge, Massachusetts: MIT Press.

Mol, L. and T. Sternberg (eds). 2012. Changing Deserts: Integrating People and their Environment. Cambridge: White Horse Press.

Nicholson, C.T.M. 2014. 'Climate change and the politics of causal reasoning: the case of climate change and migration'. The Geographical Journal 180: 151-160.

Nunn, P.D. 1988. Future Sea-Level Rise in the Pacific. SSED Working Paper No. 12, SSED (School of Social and Economic Development). Suva: University of the South Pacific.

Nunn, P.D. 1990. 'Recent Environmental Changes on Pacific Islands'. The Geographical Journal 156: 125-140.

Nunn, P.D. 2000. 'Environmental Catastrophe in the Pacific Islands Around A.D. 1300'. Geoarchaeology 15: 715-740.

Nunn, P.D. 2001. 'Ecological Crises or Marginal Disruptions: the Effects of the First Humans on Pacific Islands'. New Zealand Geographer 57: 11-20.

Nunn, P.D. and J.M.R. Britton. 2001. 'Human-Environment Relationships in the Pacific Islands around AD 1300'. Environment and History 7: 3-22.

Nunn, P.D., R. Hunter-Anderson, M.T. Carson, F. Thomas, S. Ulm and M.J. Rowland. 2007. 'Times of Plenty, Times of Less: Last-Millennium Societal Disruption in the Pacific Basin'. Human Ecology 35: 385-401.

O'Keefe, P. and C. Conway. 1977. Natural Hazards in the Windward Islands, Bradford Disaster Research Unit Occasional Paper 14. Bradford: University of Bradford.

O'Keefe, P., K. Westgate and B. Wisner. 1976. 'Taking the naturalness out of natural disasters'. Nature 260: 566-567.

Patterson, B.R. 1977. Geological Aspects of the Tonga Earthquake: 23 June 1977. Lower Hutt: Department of Scientific and Industrial Research.

Pelling, M. and J.I. Uitto. 2001. 'Small island developing states: Natural disaster vulnerability and global change'. Environmental Hazards 3: 49-62.

Pelling, M. and B. Wisner, B. (eds). 2009. Disaster Risk Reduction: Cases from urban Africa. London: Earthscan.

Perez, A., H. Fernadez and C. Gatti (eds). 2010. Building Resilience to Climate Change: Ecosystem-based Adaptation and Lessons from the Field. Gland: IUCN.

Pilkey, O.H. and R. Young. 2009. The Rising Sea. Washington, D.C.: Island Press.

Rankey, E.C. 2011. 'Nature and stability of atoll island shorelines: Gilbert Island chain, Kiribati, equatorial Pacific'. Sedimentology 58: 1831-1859.

Renaud, F.G., K. Sudmeier-Rieux and M. Estrella (eds). 2013. The Role of Ecosystems in Disaster Risk Reduction. Tokyo: United Nations University Press. 
Revelle, R. and H.E. Suess. 1957. 'Carbon Dioxide Exchange Between Atmosphere and Ocean and the Question of an Increase of Atmospheric CO, during the Past Decades'. Tellus 9: 18-27.

Rogers, G. 1981. 'The Evacuation of Niuafo' ou, an Outlier in the Kingdom of Tonga'. The Journal of Pacific History 16: 149-163.

Shaw, R., J.M. Pulhin and J.J. Pereira (eds). 2010a. Climate Change Adaptation and Disaster Risk Reduction: An Asian Perspective. Bingley: Emerald Group Publishing Limited.

Shaw, R., J.M. Pulhin and J.J. Pereira (eds). 2010b. Climate Change Adaptation and Disaster Risk Reduction: Issues and Challenges. Bingley: Emerald Group Publishing Limited. Spillius, J. 1957. 'Natural Disaster and Political Crisis in a Polynesian Society: An Exploration of Operational Research'. Human Relations 10: 3-27.

Timmerman, P. 1981. Vulnerability. Resilience and the Collapse of Society: A Review of Models and Possible Climatic Applications. Environmental Monograph No. 1. Toronto: Institute for Environmental Studies, University of Toronto.

Townsend, C.R., M. Begon and J.L. Harper. 2003. Essentials of Ecology. Oxford: Blackwell Publishing.

UNISDR. 2005. Hyogo Framework for Action 2005-2015: Building the Resilience of Nations and Communities to Disasters. Geneva: UNISDR (United Nations International Strategy for Disaster Reduction).

van Alphen, K., M.P. Hekkert and W.G.J.H.M. van Sark. 2008. 'Renewable energy technologies in the Maldives - Realizing the potential'. Renewable and Sustainable Energy Reviews 12: 162-180.

Warner, K. and T. Afifi. 2011. 'Environmental change and migration: methodological considerations from ground-breaking global survey'. Population and Environment 33: 3-27.

Weart, S. 2008. The Discovery of Global Warming. Harvard, Massachusetts: Harvard University Press.

Webb, A.P. and P.S. Kench. 2010. 'The dynamic response of reef islands to sea-level rise: Evidence from multi-decadal analysis of island change in the Central Pacific'. Global and Planetary Change 72: 234-246.

Weichselgartner, J. 2001. 'Disaster mitigation: the concept of vulnerability revisited'. Disaster Prevention and Management 10: 85-94.

Williams, R.S., Jr. and J.G. Moore. 1983. Man Against Volcano: The Eruption on Heimaey, Vestmannaeyjar, Iceland. Denver: USGS (US Geological Survey).

Wisner, B. 1993. 'Disaster vulnerability: Scale, power, and daily life'. Geojournal 30: pp.127140.

Wisner, B., P. Blaikie, T. Cannon and I. Davis. 2004. At Risk: Natural Hazards, People's Vulnerability and Disasters, 2nd ed. London: Routledge.

Wisner, B., J.C. Gaillard and I. Kelman (eds). 2012. Handbook of Hazards and Disaster Risk Reduction. Abingdon: Routledge.

Yamamoto, L. and M. Esteban. 2014. Atoll Island States and International Law: Climate Change Displacement and Sovereignty. Heidelberg: Springer. 